Interdisciplinary Contexts of Special Pedagogy
NUMBER 30/2020

\title{
Articulation disorders of the sigmatism type and the level of self-esteem of students completing the stage of early school education. Own research conducted in the Greater Poland region
}

\begin{abstract}
Agata Trębacz, Articulation disorders of the sigmatism type and the level of self-esteem of students completing the stage of early school education. Own research conducted in the Greater Poland region. Interdisciplinary Contexts of Special Pedagogy, no. 30, Poznań 2020. Pp. 187-222. Adam Mickiewicz University Press. ISSN 2300391X. e-ISSN 2658-283X. DOI: https:// doi.org/10.14746/ikps.2020.30.10

One of the sources of a student's self-esteem at a younger school age are social comparisons within their peer group. Articulation disorders may limit the effectiveness of communication and increase the likelihood of a sense of shame, stigmatisation, peer rejection or limitation of social contacts, which may lead to the formation of a negative self-image and lower self-esteem. The research procedure was conducted in two groups of students in 10 primary schools in the Greater Poland region with the use of a reliable and valid research tool. The discussed research results constitute a part of a larger project concerning the significance of articulation disorders of the sigmatism type for interpersonal and intrapersonal attitudes and attitudes towards the world of students completing the stage of early education. In the present text, an analysis of the empirical material from the subscale: self-esteem is presented. The analysis did not reveal statistically significant differences. However, the fact that the level of self-esteem, regardless of the presence or absence of a speech impediment, in nearly $70 \%$ of all respondents remains at an average or low level is alarming.
\end{abstract}

KEY WORDS: articulation disorders, sigmatism, self-esteem, early school education, speech impediments 


\section{Introduction}

Disorders of the sound realisation of phonemes, which in speech therapy and teaching practice used to be called articulation disorders or speech impediments, constitute one of the possible areas of difficulties faced by students in their intramural and extramural everyday life. Although in the last decade a significant increase in interest in scientific discussions concerning the issues of speech diagnosis and therapy has been observed, the source literature reveals a shortage of contemporary research and publications dealing with the significance of speech disorders, understood in a wide and narrow scope, for the functioning of children of school and preschool age, with particular attention to the quality of peer relations, schoolrelated skills and achievements, social activity and cognitive competence. The publications by Barbara Sawa, Ewa M. Minczakiewicz, Grażyna Demel and Ewa M. Skorek ${ }^{1}$, which all the same significantly contributed to the development of Polish speech therapy and teaching solutions in this area, come from the second half of the $20^{\text {th }}$ and the turn of the 20th century. Currently, the perception of speech therapy in an inter- and even transdisciplinary dimension, including many other borderline sciences, e.g. medicine, neurobiology, physiotherapy, education and psychology is spread. Holistic thinking about human development and functioning, dynamic changes

1 See B. Sawa, Uwarunkowania $i$ konsekwencje psychologiczne zaburzeń mowy u dzieci, Warszawa 1991; Z. Tarkowski, E.M. Skorek, Environmental Difficulties in Schoolchildren with Speech Disorders, Cracow 2008; E.M. Skorek, Stosunki koleżeńskie dzieci z zaburzeniami mowy i ich szkolne uwarunkowania, Lubusz Scientific Society 2000; E.M. Skorek, Dzieci z zaburzeniami mowy wśród rówieśników w klasie szkolnej, Cracow 2000; E.M. Skorek, Dzieci z zaburzeniami mowy w szkole. Aspekt wychowawczy, Cracow 2008; H. Spionek, Zaburzenia rozwoju uczniów a niepowodzenia szkolne, Warsaw 1975; E.M. Minczakiewicz, Zaburzenia mowy a przystosowanie społeczne jednostki, "Rocznik Komisji Nauk Pedagogicznych PAN", no. 30, Warsaw 1983; E.M. Minczakiewicz, Społeczno-emocjonalny aspekt zaburzeń mowy dzieci i młodzieży, "Rocznik Komisji Nauk Pedagogicznych PAN", no. 38, Warsaw 1987; F. Popió1, O wadach wymowy u dzieci, [in:] Nowa Szkoła, 5, Warsaw 1959, G. Demel, Z badań nad związkiem między zaburzeniami mowy a powodzeniem szkolnym, “Życie Szkoły”, 10, Warsaw 1960. 
in social life, progress in creating new theories on the basis of related scientific disciplines and building a new methodological quality become, in a way, cognitive incentives to verify and deepen the analyses undertaken by the precursors in the study of the phenomenon, including current trends, changes and social needs.

As A. Sameroff writes, everything in the universe influences something or is influenced by something, and this in turn implies the view that the development of a child is a consequence of their dynamic and mutual interactions with the experience they acquire in the social environment. ${ }^{2}$ The transactional model of A. Sameroff combines four detailed development models for a better understanding of the rules of development of each social being: personal change model, contextual model, regulation model and representation model. The first of them assumes that human development is of specific nature and takes place in a continuous, dynamic system with critical moments that may lead to the mobilisation of development or its inhibition as a result of the occurring abnormalities. The regulation model refers to shaping self-regulation as a result of experiencing the activity and involvement of other people from the environment, and the representation model explains human activity in a specific place and time. The contextual model refers to the ecological concept of Urie Bronfenbrenner, emphasising the mutual influence of the child and the environment on their functioning. In addition, it indicates the significant importance of the family as the primary source of social experience and shows a qualitative change in social contacts at later stages, when the cooperation of the school, educational and peer group environments models the process of socialization of the child. ${ }^{3}$ In the context of the discussed issues, the concept of A. Sameroff may constitute a background for explaining the significance of articulation disorders for the level of self-esteem and for identifying the relationships between the level of self-

${ }^{2}$ A. Sameroff, A Unified Theory of Development: A Dialectic Integration of Nature and Nurture, "Child Development", vol. 81(1), 2010, p. 16.

${ }^{3}$ A. Sameroff, A Unified Theory of Development: A Dialectic Integration of Nature and Nurture, "Child Development", vol. 81(1), 2010, pp. 12-16. 
esteem and the quality of the intramural and extramural functioning of a child.

A similar point of view on the course of development was presented by Richard M. Lerner in the contextual approach. The author of the conception explains that the concept of development should be considered in the context of dynamic, systematic and orderly changes in society, and above all in each person individually. However, manifested individual changes are not indifferent to other participants of social life, because even the smallest change in human functioning leads to changes in other subsystems that remain inseparable and covariant towards each other. Although in this approach it is recognised that a human being actively participates in shaping the path of their own development on the social, emotional and cognitive level, the context in which a given development takes place is also an important element. ${ }^{4}$ This view of development shows that a speech impediment may cause a change in the level of students' self-esteem, and thus determine the quality of their life in the educational and upbringing environment.

An important model of explanation may also be the model of the development of the sense of learned helplessness of John Kirby and Noel Henry Williams, in which failure, understood in this case as abnormalities in the development of the phonetic and phonological system, is perceived by other people from the environment (e.g. peers, teachers, parents or siblings) and leads to doubts in the area of one's own " $\mathrm{I}$ ", consequently resulting in the consolidation of negative judgements about oneself. ${ }^{5}$

Earlier reports by the researchers of the issue indicate a significant significance of speech disorders for the psychosocial functioning of a child, especially in relation to peer interactions, teacher-student relationship, social position, emotional acceptance, motivation, intrapersonal attitudes, as well as school readiness of six-year-old chil-

${ }^{4}$ R.M. Lerner, D.V. Hultsch, Human Development. A life-span perspective, McGrawHill 1983, pp. 5-6.

${ }^{5}$ J.R. Kirby, N.H. Williams, Learning Problems. A Cognitive Approach. Toronto 1991. 
dren 6 However, nowadays the image of speech impediments is very complex, because it includes disorders related to perceptual and realisation-related abnormalities. Moreover, the mentioned abnormalities may have a different aetiology, present a different degree of severity, and may concern one, two or more language subsystems, e.g. syntactic, phonological or lexical one. This seems to be important from the point of the present considerations and the research planned in this area, suggesting that the study group in which the researcher conducts the observation should be homogeneous in terms of the type and severity of the occurring speech impediment, in order to allow for the formulation of objective conclusions.

In recent years, the size of the population of children with speech disorders has been estimated at several to several dozen percent, and according to E.M. Minczakiewicz, it should be considered controversial. The study of the aforementioned author, conducted in 1979-1989 in groups of preschool students, showed that speech disorders were revealed by nearly $40 \%$ of the students. In turn, in 1985, a team of researchers led by H. Spionek found out that the severity of the occurrence of speech disorders among primary school students is approximately $19.2 \% .^{7}$

${ }^{6}$ Zob. M. Kielar-Turska, Sprawności językowe i komunikacyjne a inne funkcje psychiczne, [in:] Logopedia - wybrane aspekty historii, teorii i praktyki, ed. S. Milewski, K. Kaczorowska-Bray, Harmonia Universalis, Gdańsk 2012, pp. 70-85; E.M. Skorek, Dzieci z zaburzeniami mowy w szkole. Aspekt wychowawczy, Oficyna Wydawnicza Impuls, Cracow 2008; M. Zając, Zaburzenia rozwoju mowy a samoocena dziecka, [in:] Terapia logopedyczna, ed. D. Baczała, J.J. Błeszyński, Wydawnictwo Naukowe Uniwersytetu Mikołaja Kopernika, Toruń 2014, pp. 237-256; A. Jopkiewicz, Konsekwencje społeczne, psychologiczne i pedagogiczne nieprawidłowego rozwoju mowy u dzieci, "Acta Scientifica Academiae Ostroviensis" no. 8, 2001, Ostrowiec Świętokrzyski, pp. 113-123; G. Lindsay, J. Dockrell, The behaviour and self-esteem of children with specific speech and language difficulties, "British Journal of Educational Psychology" vol. 70, Great Britain 2000, pp. 583-601; G. Lindsay, J. Dockrell, C.J. Mackie, Self-esteem of children with specific speech and language difficulties, "Child Language Teaching and Therapy", 2002, pp. 125-143; A. Frydrychowicz, E. Koźniewska, A. Matuszewski, E. Zwierzyńska, Skala gotowości szkolnej, Methodological Centre of Psychological-Pedagogical Counselling, Warsaw 2006.

${ }^{7}$ E.M. Minczakiewicz, Dyslalia na tle innych wad i zaburzeń mowy u dzieci w wieku przedszkolnym i szkolnym, “Konteksty Pedagogiczne” 1(8), 2017, pp. 154-155. 
According to the latest data, the most common form of speech impediments among students preparing to start their education in the first grade of primary school includes distortions in the field of sound realisation of phonemes. In the 2014/2015 school year, a group of postgraduate speech therapy students and students of special education under the supervision of E. Minczakiewicz conducted research on the school situation of students with speech impediments (including speech sound disorders). The diagnostic survey method was used. The screening tests covered 1,200 students in grades 0-6 from 18 randomly selected primary schools in southern Poland. Two primary objectives of the procedure were defined: 1) recognising and determining the size and type of speech impairments and impediments revealed by students, as well as 2) identifying the social position of students with speech impediments in their grade and the level of their social adaptation. From the aforementioned group of people, a group of 184 children with a diagnosis of speech impairments and impediments was selected, which constituted $15.33 \%$ of the general study population. Pictorial questionnaire for testing the pronunciation of reading and not reading children by $\mathrm{T}$. Bartkowska (1968) was used to assess the articulation and it was observed that the most frequent disorders in this group of students were incorrect sound realizations of phonemes $(61.5 \%){ }^{8}$

The data collected in Table 1 reveal one more regularity observed in practice, that the rate of speech impediments in groups of students decreases with age (from $25 \%$ at the level of the preschool grades to $5.43 \%$ at the level of the sixth grades of primary school). However, among students completing the stage of early school education, it remains at the level of almost $11 \%$.

The initial analysis of other research results obtained by the same author (the research is ongoing), conducted in the school year $2014 / 2015$ on a sample of 1,248 preschool grade students ( $\geq 7$ years old), both in preschool and school formd, suggests that the speech

${ }^{8}$ E.M. Minczkiewicz, Dyslalia na tle innych wad i zaburzeń mowy u dzieci w wieku przedszkolnym i szkolnym, “Konteksty Pedagogiczne” 1(8), 2017, pp. 158-160. 
Table 1. Scope of speech impediments in primary school students compared to other students in the form

\begin{tabular}{|c|c|c|c|c|c|c|c|c|}
\hline \multirow{3}{*}{ Grade } & \multirow{2}{*}{\multicolumn{2}{|c|}{$\begin{array}{l}\text { Number of } \\
\text { students in the } \\
\text { form }\end{array}$}} & \multirow{2}{*}{\multicolumn{2}{|c|}{$\begin{array}{l}\text { Scope of disor- } \\
\text { ders in students } \\
\text { with speech } \\
\text { impediments }\end{array}$}} & \multicolumn{4}{|c|}{$\begin{array}{l}\text { Speech impediments in students } \\
\text { and the gender of the respondents }\end{array}$} \\
\hline & & & & & \multicolumn{2}{|c|}{ Girls } & \multicolumn{2}{|c|}{ Boys } \\
\hline & $n$ & $\%$ & $n$ & $\%$ & $n$ & $\%$ & $n$ & $\%$ \\
\hline 0 & 272 & 100 & 68 & 25.00 & 27 & 39.70 & 41 & 60.30 \\
\hline 1st grade & 308 & 100 & 57 & 18.50 & 16 & 28.10 & 41 & 71.09 \\
\hline 2nd grade & 123 & 100 & 23 & 18.70 & 12 & 52.20 & 11 & 47.80 \\
\hline 3rd grade & 146 & 100 & 16 & 10.96 & 8 & 50.00 & 8 & 50.00 \\
\hline 4 th grade & 128 & 100 & 8 & 6.25 & 1 & 12.50 & 7 & 87.50 \\
\hline 5 th grade & 131 & 100 & 7 & 5.34 & 3 & 42.80 & 4 & 57.20 \\
\hline 6th grade & 92 & 100 & 5 & 5.43 & 1 & 20.00 & 4 & 80.00 \\
\hline Total & 1200 & 100 & 184 & 15.33 & 68 & 37.00 & 116 & 63.00 \\
\hline
\end{tabular}

Source: E. M. Minczakiewicz, Dyslalia na tle innych wad i zaburzeń mowy u dzieci w wieku przedszkolnym i szkolnym, [in:] Konteksty Pedagogiczne 1(8)/2017, Warsaw, p. 160.

disorder rate in this group of students is approx. $24.6 \% .{ }^{9}$ This result corresponds to the assumptions of the employees of the Department of Logopaedics and Applied Linguistics at the Maria Curie-Skłodowska University in Lublin that the severity of speech impediments on a national scale in the group of students at the threshold of primary school can be estimated at approx. $25 \% . .^{10 *}$

${ }^{9}$ E.M. Minczkiewicz, Dyslalia na tle innych wad i zaburzeń mowy u dzieci w wieku przedszkolnym i szkolnym, „Konteksty Pedagogiczne” 1(8), 2017, p. 155. The present research procedure was of indicative and prognostic nature. To assess articulation, Pictorial questionnaire for testing the pronunciation by G. Demel (1978) was used. Although the research is still ongoing, the preliminary analysis of the collected research results revealed that the most common speech impediment in this group of students includes articulation disorders - which are present in nearly $63 \%$.

10 Department of Health and Social Policy of the Marshal Office of Lesser Poland Voivodeship, Regional Health Program of Lesser Poland Voivodeship. J. Tomik, B. Solowska, Wczesne wykrywanie wad rozwojowych u dzieci w wieku szkolnym w zakresie zaburzeń stuchu i wad wymowy, Cracow 2018, p. 10.

* These are only estimates, not confirmed by empirical research. 
Similarly, in the 2016/2017 school year, employees and doctoral students of the Department of Polish Dialectology and Logopaedics of the University of Łódź conducted speech screening tests among grade 1-3 students of one of the primary schools in Łódź. The aim of the procedure was to determine articulation problems and to assess the structure and performance of the orofacial apparatus of these students. The articulation was assessed on the basis of selected pictures from Speech therapy test for children and youth, developed by Iwona Michalak-Widera (2009). ${ }^{11}$ Out of 150 children subjected to the test, 71 revealed symptoms of articulation disorders, which accounted for $47 \%$ of the respondents. As it results from the data collected in Table 2, among the paradigmatic disorders, the most frequent abnormalities were non-normative realizations of dentalised phones of the rustling series (59\% of students, including $25 \%$ at the 3rd grade level). ${ }^{12}$

Table 2. Types of speech impediments in the tested grade 1-3 students of primary schools

\begin{tabular}{|c|c|c|c|c|c|c|c|c|c|c|c|c|}
\hline $\begin{array}{l}\text { Types of phoneme } \\
\text { groups realised in a }\end{array}$ & \multicolumn{2}{|c|}{$\check{s}, \check{z}, \check{c}, \check{z}$} & \multicolumn{2}{|c|}{$s, z, c, 3$} & \multicolumn{2}{|c|}{$l$} & \multicolumn{2}{|c|}{$k$} & \multicolumn{2}{|c|}{$g$} & \multicolumn{2}{|c|}{$t, d, n$} \\
\hline Grade & $n$ & $\%$ & $n$ & $\%$ & $n$ & $\%$ & $n$ & $\%$ & $n$ & $\%$ & $n$ & $\%$ \\
\hline 1st grade & 9 & 13 & 5 & 7 & 0 & 0 & 3 & 4 & 3 & 4 & 0 & 0 \\
\hline 2nd grade & 15 & 21 & 16 & 14 & 0 & 0 & 2 & 3 & 2 & 3 & 2 & 3 \\
\hline 3rd grade & 18 & 25 & 8 & 11 & 1 & 1 & 0 & 0 & 0 & 0 & 0 & 0 \\
\hline Total: & 42 & 59 & 29 & 41 & 1 & 1 & 5 & 7 & 5 & 7 & 2 & 3 \\
\hline
\end{tabular}

Source: E. Gacka, M. Kaźmierczak, Przesiewowe badania mowy jako przykład działań z zakresu profilaktyki logopedycznej, “Logopaedica Lodziensa” no. 1, ed. I. Jaros, Łódź 2017, p. 38.

11 The pictures of objects and phenomena, whose names usually contain incorrectly realised phonemes, or $s z, r z / \dot{z}, c z, d \dot{z}, s, z, c, d z, s, \dot{z}, \dot{c}, d \dot{z}, r, l, j$ were used selectively.

12 E. Gacka, M. Kaźmierczak, Przesiewowe badania mowy jako przykład działań z zakresu profilaktyki logopedycznej, [in:] Logopaedica Lodziensa nr 1, ed. I. Jaros, Łódź 2017, pp. 35-41. 
Other analyses of the results of the studies concerning this issue also confirm that the incorrectly realised groups of phonemes in groups of children of 3;3-6;11 and 7;0-13;1 with peripheral dyslalia are most often dentalised phones of the rustling series $(>95 \%$ of the respondents) and the hissing series (> 75\% of the respondents). ${ }^{13,14}$

Although the normative realization of dental phones should be fixed in the phonological system until the child turns 5 years of age, the above-mentioned analyses of the research results confirm the opinion known from the source literature that the described articulation disorder (sigmatism, lisp) is invariably the most common speech impairment in the preschool and early school period. ${ }^{15}$

13 The study carried out by D. Pluta-Wojciechowska in a group of 69 patients with isolated phoneme realization disorders of peripheral aetiology in the Lesser Poland and Silesian Voivodeship in 2014-2018. Based on the age criterion, the author distinguished 3 smaller study groups in the research sample: 3;3-6;11 $(n=23)$, $7 ; 0-13 ; 1(n=23)$ and 15;0-40;0 ( $n=23)$. Because of the fact that the issues discussed in the present article concern children of early school age, only the results obtained in the first two groups were mentioned. Incorrect realizations of the phones of the rustling series ( $\breve{s}, \check{z}, \breve{c}, \breve{3}$ ) were recognised in $44 / 46$ people $(>95 \%)$, and $36 / 46$ people $(>75 \%)$ presented incorrect realizations of the phones of the hissing series $(\mathrm{s}, \mathrm{z}, \mathrm{c}, 3)$. The report on the results of the study is discussed in detail in the monograph Efektywność terapii dyslalii. Logopedyczno-lingwistyczna analiza wyników badań by D. Pluta=Wojciechowska (Wydawnictwo Uniwersytetu Śląskiego, Katowice 2019).

14 There is little data on the scale of severity of speech impediments among students at particular educational stages. Particularly, there is a lack of studies that would allow for the determination of the size of the phenomenon on a national scale. All the studies discussed in the text were of a regional nature.

15 See J.T. Kania, Szkice logopedyczne, Wydawnictwo Szkolne i Pedagogiczne 1982; G. Jastrzębowska, Podstawy teorii i diagnozy logopedycznej, Studia i Monografie no. 263, Wydawnictwo Uniwersytetu Opolskiego, Opole 1998; E. Jeżewska-Krasnodębska, Przyczyny zaburzeń artykulacji zlokalizowane w układzie obwodowym, Oficyna Wydawnicza Impuls, Cracow 2015; E. Gacka, M. Kaźmierczak, Przesiewowe badania mowy jako przykład działań z zakresu profilaktyki logopedycznej, "Logopaedica Lodziensa" no. 1, ed. I. Jaros, Łódź 2017, ed. 35-34; E.M. Minczakiewicz, Dyslalia na tle innych zaburzeń wad $i$ zaburzeń mowy u dzieci w wieku przedszkolnym i szkolnym, "Konteksty Pedagogiczne PAN 1(8), Bielsko-Biała 2017, pp. 149-169; D. Pluta-Wojciechowska, Efektywność terapii dyslalii. Logopedyczno-lingwistyczna analiza wyników badań, Wydawnictwo Uniwersytetu Śląskiego, Katowice 2019. 
The above findings determined the selection of the research sample, which included children with disorders of the sound realization of dentalised phonemes. ${ }^{16}$

The school period, called the last stage of childhood in human development, is the most dynamic stage of own Self development as a result of improving cognitive functions and enriching social competences. In that period, the child faces numerous developmental challenges, the most important of which are building a sense of competence and shaping self-esteem. ${ }^{17}$ During this period, the importance of comparing one's own skills with the skills of friends grows, which is manifested in the form of "tries", "bets", e.g. who will reach the pitch faster. Such confrontations allow for the development of knowledge about oneself, on the continuum of which there are both good experiences influencing a positive self-image, as well as negative ones that contribute to lower self-esteem. ${ }^{18}$

Self-esteem is a concept defined on the basis of various disciplines, including psychology, sociology, education or anthropology. In psychology, and especially in personality psychology, self-esteem is defined as "the function of the difference between the ideal self and the real self" ${ }^{19}$ The concept of the Self refers to the cognitive aspects of the Self system and denotes the subjective knowledge that each person has about themselves, which changes over the life cycle under the influence of social experiences. The size of the disproportion between the two indicated dimensions of the Self determines the level of selfesteem. And so, if there is no significant difference between them, it is called a high level of self-esteem. However, the greater the discrepancy between the real Self and the ideal Self, the poorer self-image. ${ }^{20}$

16 Dentalised phonemes: [s], [z], [c], [3], [š], [ž], [č], [̌̌] , [ś], [ź], [ć], [3́]

${ }^{17}$ E. Erikson, Dzieciństwo i społeczeństwo, translated by Przemysław Hejmej, Dom Wydawniczy Rebis, Poznań 1997, pp. 269-272.

18 T. Lewandowska-Kidon, D. Wosik-Kowala, Rozwijanie poczucia własnej wartości u dzieci w młodszym wieku szkolnym, Cracow 2009, pp. 20-24.

${ }^{19}$ M. Szpitlak, R. Polczyk, Samoocena. Geneza, struktura, funkcje i metody pomiaru, Wydawnictwo Uniwersytetu Jagiellońskiego, Cracow 2015, p. 10.

${ }^{20}$ H.R. Schaffer, Rozwój społeczny. Dzieciństwo i młodość, Wydawnictwo Uniwersytetu Jagiellońskiego, Cracow 2006, pp. 169-184. 
According to L. Niebrzydowski, self-esteem is an isolated foundation of the social being's knowledge about themselves. ${ }^{21}$ Similarly, H. Kulas postulates that self-esteem is "a fragment of a larger organisation, an element of the human knowledge system about themselves".22

It should be added that depending on the authors and concepts, the terms self-esteem and self-image are considered to be have the same or different meaning. ${ }^{23}$ In this study, the indicated terms will be treated as synonymous.

In the applied research tool, the definition of self-esteem as "conscious attitude towards the Self and emotions related to the object, which is own Self related (...) to cognitive judgements about oneself", was adopted as the basis for drawing conclusions about the level of self-esteem in early school age children". ${ }^{24}$ The characteristics of the general self-esteem as well as the specific (detailed) self-esteem referring to particular spheres of human functioning, including the cognitive-intellectual, physical or socio-moral sphere were described. In such an approach, self-esteem is therefore a holistic assessment of own value and is expressed in the attitude of the social being towards their own Self. This attitude can have two dimensions: negative or positive. A negative attitude is a reflection of a low level of self-esteem, in which the individual rejects own Self

${ }^{21}$ L. Niebrzydowski, O poznawaniu i ocenie samego siebie, Wydawnictwo Nasza Księgarnia, Warsaw 1976, p. 52.

${ }^{22}$ H. Kulas, Samoocena młodzieży, Wydawnictwa Szkolne i Pedagogiczne, Warsaw 1986, p. 9.

${ }^{23}$ Zob. D. Tuttle, N. Tuttle, The Development of Self-esteem, [in:] Self-esteem and Adjusting with Blindness, red. D. Tuttle, N. Tuttle, Springfield 2004; J. Kata, Poczucie wtasnej wartości u młodzieży. Wymiar teoretyczny i praktyczne implikacje, "Nauczyciel i Szkoła" 2018/3, no. 67, pp. 95-104; J. Kozielecki, Psychologiczna teoria samowiedzy, Wydawnictwo Naukowe PWN, Warsaw 1986, A. Zbonikowski, Poczucie własnej wartości dziecka z ograniczeniami w rozwoju, "Pedagogika Rodziny 1/3/4", 2011, pp. 59-68.

24 J. Góźdź, E. Wysocka, The Questionnaire on Intrapersonal and Interpersonal Attitudes and those Towards the World (QIIATW). Podręcznik testu - wersji dla uczniów szkoty podstawowej klas I-III, Warsaw 2011, p. 11. 
and manifests chronic dissatisfaction with the undertaken activities. In the case of a positive attitude, the individual presents a high level of self-esteem and feels a valuable, socially important person. ${ }^{25}$

Based on the above considerations, it can be concluded that the level of self-esteem has an impact on the school functioning of students. In the early school period, the student learns about themselves based on the increasingly deeper self-reflection, based on social comparisons, based on relationships with teachers and parents, or based on feedback from the environment, including peers who set criteria for success and failure. ${ }^{26}$ In the literature, there are several criteria for the division of self-esteem, including the degree of generality, durability, value, level or compliance and validity of the self-esteem with the actual capabilities of the individual. The last two criteria have been adopted as the basis for the considerations in the present paper. Considering the indicator of the level of self-esteem, high self-esteem, which is characterised by satisfaction with undertaken activities and oneself, and low self-esteem, characterised by low faith in the possessed capabilities and the belief to be worse than others, can be distinguished. In the case of the second criterion, or the compliance and validity of the self-esteem with the actual abilities of the individual, adequate and inadequate self-esteem is indicated. The self-esteem can be called adequate when a person properly assesses their own abilities. In turn, inadequate self-esteem is manifested in two dimensions and is the result of the inability of a person to objectively evaluate their own skills. The first dimension of inadequate self-esteem is lowered self-esteem, when a person incorrectly evaluates their own abilities, does not believe in themselves and rejects faith in success. At the opposite extreme is inflated self-esteem, characterised by a tendency to overestimate own abilities and overconfidence. ${ }^{27}$

${ }^{25}$ M. Rosenberg, Society and adolescent self-image, Princeton University Press, New York 1965, pp. 30-31.

26 A. Jędrzejewska, Samoocena dziecka - źródła i komunikaty weryfikujące, "Zbliżenia Cywilizacyjne" no. 1(1) 2016, pp. 144-161.

27 P. Borowiecki, Samoocena osób z niepetnosprawnościa w świetle wybranej literatury i badań własnych, "Niepełnosprawność - zagadnienia, problemy, rozwiązania" 
Thanks to the experience of joy resulting from own successes and achievements and a favourable attitude of the environment, students develop high, realistic self-esteem, which makes them resistant to school failures and difficulties, strengthens their determination in achieving set goals and supports the development of peer relationships. ${ }^{28}$ A parent who wants to activate the development of adequate self-esteem in a child should believe in their individual abilities, be consolation in failures, strengthen their positive qualities, be an attentive listener, set real expectations and requirements, and apply the so-called constructive discipline that relates to the behaviour and not directly to the child as a human being. In addition, they should avoid unjustified negative comments and evaluations, consider the feelings of the child, and also be an example of high self-esteem in order to be a role model for the child. ${ }^{29}$

Bearing in mind that during the school period, the role of other significant people from outside the family environment of the child, including teachers, increases, it can be assumed that similar behaviours should be presented by the teacher in interactions with students to support them in the process of the development of adequate self-esteem. According to N. Branden, teachers with high self-esteem are able to perceive the potential of a student, while those with low self-esteem focus mostly on the weaknesses and imperfections of their pupils. ${ }^{30}$ In the everyday work, a teacher should respect the subjectivity and individuality of students, fairly assess their achievements, minimise competitive behaviour, promote group initiatives and community activities, as well as be a vigilant

no. II/2015(15), [after:] D. Wosik-Kawala, Korygowanie samooceny uczniów gimnazjum, Lublin, Wydawnictwo UMCS, 2007.

28 A. Jędrzejewska, Samoocena dziecka - źródła i komunikaty weryfikujące, "Zbliżenia Cywilizacyjne" no. 1(1) 2016, pp. 146-147.

${ }^{29}$ M. Ryś, Ksztattowanie się poczucia własnej wartości $i$ relacji z innymi w różnych systemach rodzinnych, "Kwartalnik naukowy" 2(6), 2011, p. 77.

${ }^{30}$ N. Branden, 6 filarów poczucia wtasnej wartości (translated by H. Dąbrowska), Wydawnictwo Ravi, Łódź 1998, pp. 220-221. 
observer of students' behaviour, to cooperate with specialists if necessary and at the right moment. ${ }^{31}$

An important background for the development of self-esteem is the quality of the relationship and the student's status in the peer group. The student gets to know themselves, their strengths and weaknesses, as a result of social comparisons with peers. Not always the individual self-image perceived through the eyes of a student is consistent with the ideas of other people, which is not without significance for their self-esteem. The more different these two positions are, to the disadvantage of the student, the lower self-esteem. A child who is appreciated and liked by peers has a greater chance of developing high, adequate self-esteem, as peer acceptance is the foundation that strengthens the development of self-image. ${ }^{32}$

The feeling of inadequacy in relation to the imposed social expectations, the feeling of lack of support from the family, peers and the educational environment, as well as failure in tasks resulting from the role of a student, shape a low level of self-esteem in the student, which may consequently lead to a reduction in their development potential, cause a feeling of uselessness and shame, arouse fear of changes and a tendency to give up, as well as limit interaction with the social environment. ${ }^{33}$ As mentioned earlier, the sense of being accepted and appreciated in the peer group has a significant impact on the self-esteem of a student, therefore all manifestations of rejection and loss of social position in a group of friends

${ }^{31}$ R. Biernat, Troska o poczucie własnej wartości dzieci w rzeczywistości szkolnej wymiar teoretyczny i praktyczne implikacje, "Społeczeństwo. Edukacja. Język" no. 4, 2016, p. 162.

32 M. Supińska, Dzieci izolowane i odrzucone, "Życie Szkoły” no. 2, 2003, p. 89, [after:] R. Biernat, Troska o poczucie własnej wartości dzieci w rzeczywistości szkolnej wymiar teoretyczny i praktyczne implikacje, "Społeczeństwo. Edukacja. Język" no. 4, 2016, p. 163.

${ }^{33}$ K. Appelt, Wiek szkolny. Jak rozpoznać potencjat dziecka?, [in:] Psychologiczne portrety człowieka. Praktyczna psychologia rozwojowa, ed. A. I. Brzezińska, Gdańskie Wydawnictwo Psychologiczne, Gdańsk 2019, pp. 274-295. 
lower the self-esteem of children and may intensify the feeling of loneliness. ${ }^{34}$ The source of lowered self-esteem in students may also include educational mistakes of parents, and M. Ryś notices them, among others, in critical and unfriendly comparisons of own child with peers, in constant pointing out mistakes, failure to respect individual views and opinions of the child, or in unjustified punishment and use of violence. ${ }^{35}$

Articulation disorder is a type of abnormality that, to a greater or lesser extent, can determine the quality of the functioning of a child. Between 7-8 years of age, the child develops general self-esteem, referring not only to specific assessments (e.g. sports achievements, school achievements), but to the person as a whole. ${ }^{36}$ Abnormalities in sound realizations may indirectly affect self-esteem because of the increased probability of a sense of shame, peer rejection or limited social contacts as a result of accompanying deficits. The accumulation of negative experiences in contacts with others by a student with impaired articulation, does not remain indifferent to the knowledge they develop about themselves, because of the incomprehensibility of the transmitted messages. Communication is one of the key tools which serve the adaptation of a person to social life, therefore any deviations in this area may lead to withdrawal from the relationship, lack of a sense of competence, reduced pleasure and joy from contacts, avoiding social exposure, and finally to lowered self-esteem.

34 See R. Biernat, Troska o poczucie własnej wartości dzieci w rzeczywistości szkolnej wymiar teoretyczny i praktyczne implikacje, "Społeczeństwo. Edukacja. Język" no. 4, 2016, pp. 162-163; A. Jędrzejewska, Samoocena dziecka - źródła i komunikaty weryfikujące, “Zbliżenia Cywilizacyjne” no. 1(1) 2016, p. 147; M. Knopik, Zaburzona komunikacja a relacje społeczne. Zagrożenia i strategie wsparcia, [in:] Uczeń ze specjalnymi potrzebami edukacyjnymi, ed. E. Domagała-Zyśk, Lublin 2012, p. 36.

35 M. Ryś, Ksztattowanie się poczucia własnej wartości $i$ relacji z innymi w różnych systemach rodzinnych, "Kwartalnik naukowy" 2(6), 2011, p. 79.

${ }^{36}$ H.R Schaffer., Rozwój społeczny. Dzieciństwo i młodość, Wydawnictwo Uniwersytetu Jagiellońskiego, Cracow 2006, pp. 169-184. 
A person with a speech impairment may perceive their difficulties as stigmatising, embarrassing and feel an incompetent interlocutor, which in turn may reduce the motivation to be active and lower self-esteem in many areas. ${ }^{37}$

\section{Methodology and results of own research}

The results of the research discussed in this part of the paper are a fragment of a wider study on the significance of disorders of the sound realization of dentalised phonemes for intrapersonal and interpersonal relationships, as well as attitudes towards the world of children completing the early school education stage in the Greater Poland region. ${ }^{38}$ The study was conducted in the period from December 2018 to February 2019 in ten primary schools in the Greater Poland Voivodeship in two groups of 3rd grade students, or a group of students revealing sigmatism-type articulation disorders and a group of students without articulation disorders. A total of 69 students were the subject of the study. One of the observations was considered an outlier and it was finally decided not to include it in the analyses, even though the result of the boy did not affect the differences between the study groups in the Student's t-test and in the comparison of the Student's t-test results with the MannWhitney U test (Table 3.) Excluding the outlier allowed for two equal 34-people research samples. A box plot was used to graphically present the observations (Figure 1). The score of the boy on the self-esteem scale was 13/40 points. The form master explained that the boy began his education in 1st grade as a six-year-old, but the

${ }^{37}$ M. Knopik, Zaburzona komunikacja a relacje społeczne. Zagrożenia $i$ strategie wsparcia, [in:] Uczeń ze specjalnymi potrzebami edukacyjnymi, ed. E. Domagała-Zyśk, Lublin 2012, pp. 30-36.

38 The author's own research conducted as part of the master's thesis entitled "The significance of articulation disorders of the sigmatism type for intrapersonal and interpersonal attitudes and attitudes towards the world of children completing the stage of early school education in the Greater Poland region". 
increasing difficulties in learning to read and write prompted the mother to decide that the boy would repeat 3rd grade in the year of the study.

Table 3. Results of the tests of significant difference and the Mann-Whitney test

\begin{tabular}{|l|c|c|}
\multicolumn{1}{c}{ Test } & \multicolumn{1}{c}{ Result } & p-value \\
\hline Student's t (69 people) & 0.143 & 0.887 \\
\hline Student's t (68 people) & 0.583 & 0.562 \\
\hline
\end{tabular}

Mann-Whitney U

562

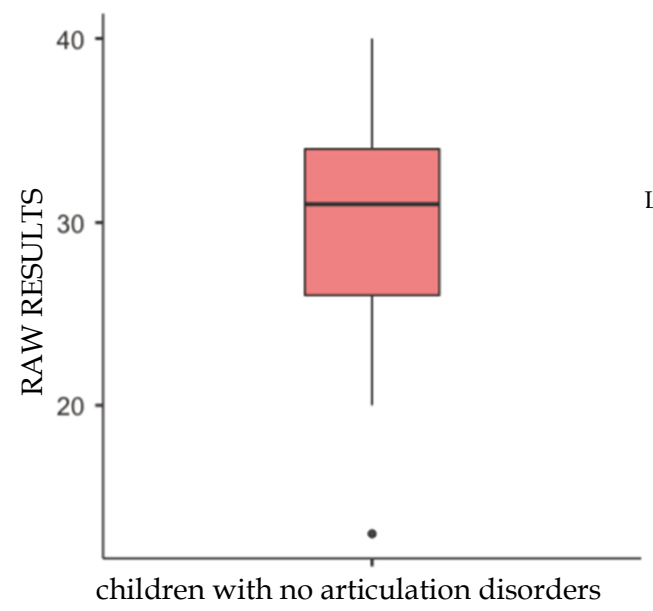

Lower outlier (calculations):

$13 \leq \mathrm{Q} 1-\mathrm{IQR}^{*} 1.5$

$\mathrm{Q} 1=26.3 \mathrm{pt}$

$\mathrm{IQR}^{*} 1.5=10.05$

$13 \leq 16.25$

Fig. 1. Self-esteem An outlier in a group of children without articulation disorders of the sigmatism type

The collected empirical data are products of a diagnostic measurement that is part of the area of exploratory research. The indicated type of research allows for the identification of a phenomenon in a research sample which is of interest for the researcher, thanks to the answer to the problem question posed earlier, which gives direction to the entire research procedure. Exploratory research does 
not verify theoretical statements with the intention of confirming or falsifying them, but allows for the collection of tips and ideas for building a theory. Therefore, in such studies hypotheses are not formulated, as their main goal is to describe the existing reality, without considering the relationship between dependent and independent variables. ${ }^{39}$

When designating the purpose of the study in relation to the research methodology, it was assumed that it was to determine the significance of disorders of the sound realization of dentalised phonemes for the level of self-esteem of students completing the stage of early school education. As part of the research aim defined in this way, the main problem and three detailed problems were formulated, and then answers were sought in the course of the analysis and interpretation of the collected data:

1 . What is the level of self-esteem of 3rd grade students revealing disorders of the sound realization of dentalised phonemes and not revealing articulation disorders, and what are the differences between the study groups in this respect?

1.1. What is the level of self-esteem of 3rd grade students revealing articulation disorders of the sigmatism type?

1.2. What is the level of self-esteem of 3rd grade students not revealing articulation disorders?

1.3. Does the level of self-esteem differ in the study groups of students with articulation disorders of sigmatism type and without articulation disorders and in which way?

In order to recognise the level of self-esteem of the students, a research tool created by Joanna Góźdź and Ewa Wysocka, or The Questionnaire on Intrapersonal and Interpersonal Attitudes and those Towards the World (QIIATW) - in a version for 1-3 grade students of primary schools was used. 40 The theoretical basis of the questionnaire is the cognitive theory of personality, the fundamen-

${ }^{39}$ K. Konarzewski, Jak uprawiać badania oświatowe. Metodologia praktyczna, WSiP, Warsaw 2000, pp. 12-47.

40 Publishing house: Ministry of National Education, Cracow 2011. 
tal assumptions of which focus on the content of how a human being understands the world and themselves, and how they function in the surrounding world adequately to internalised beliefs about this world and themselves. Finally, after the verification of the pilot studies and the actual studies, the questionnaire contained a total of 59 statements relating to four scales:

\section{1 . self-esteem,}

2. Interpersonal relationships - with two subscales:

a. me towards others,

b. others towards me,

3. belief in self-efficacy vs. learned helplessness with two subscales:
a. intramural situations,
b. extramural situations,

\section{4. basic hope.}

The results of the reliability analyses for the self-esteem scale (Cronbach's alpha $=0.68$ and Spearman-Brown coefficient $=0.62$ ) allow the presented tool to be considered reliable and applicable for scientific purposes. Kendall's W coefficient of concordance was 0.530 ( $p=0.001$, which is the basis for adopting the opinion that the items making up the individual scales of the QIIATW (PS 1-3) relate to the area defined in theoretical assumptions to a large or very large extent. ${ }^{41}$ However, the analysis showed the presence of statistically significant differences between the mean scores of girls and boys, therefore the normal sten scores of the questionnaire scales were calculated individually for the group of girls and boys. In addition, it was found that the results in the range between 7 and 10 sten are considered high, between 5 and 6 sten as average, and the results $\leq 4$ as low.

The selection of students for the research samples was purposive, because it was important to create two separate groups that would

41 J. Góźdź, E. Wysocka, Kwestionariusz Nastawień Intrapersonalnych, Interpersonalnych i Nastawień wobec Świata (KNIIŚ). Podręcznik testu - wersja dla uczniów szkoły podstawowej klas I-III, Ministry of National Education, Warsaw 2011, pp. 39-41. 
meet certain conditions and thanks to which it would be possible to formulate answers to the posed problem questions. Due to the minority of respondents, parents were previously asked to provide their consent for the participation of their child in the study. Children with articulation disorders of the sigmatism type were selected by a school speech therapist working in a given educational institution. However, earlier, the author of the study met the speech therapist to clarify the criteria for qualifying students to the research samples (Table 4 and Table 5). Although in the latest reports it is

Table 4. Criteria for inclusion in the research sample

\begin{tabular}{|l|l|}
\hline $\begin{array}{c}\text { Children with disorders of the sound } \\
\text { realization of dentalised phonemes }\end{array}$ & $\begin{array}{c}\text { Children without disorders } \\
\text { of the sound realization of phonemes }\end{array}$ \\
\hline 3rd grade students of primary school \\
\hline Polish as the mother tongue \\
\hline area: Greater Poland Voivodeship \\
\hline students without global developmental disorders; within the intellectual norm \\
\hline $\begin{array}{l}\text { children revealing disorders of the sound } \\
\text { realization of dentalised phonemes }\end{array}$ & $\begin{array}{l}\text { children not revealing disorders of the } \\
\text { sound realization of dentalised phonemes }\end{array}$ \\
\hline
\end{tabular}

postulated to depart from the traditional, auditory assessment of articulation disorders in favour of a causal and symptomatic multisensory diagnosis ${ }^{42}$, only those children whose deviations from the articulation standard can be identified on the basis of auditory assessment were included in the designed research procedure. It was important because of the fact that the abnormalities in the sound substance can be noticed by any person not being a speech therapist, including children.The total number of respondents was 68 children completing the stage of early school education, including:

42 See. D. Pluta-Wojciechowska, Dyslalia obwodowa. Diagnoza i terapia logopedyczna wybranych zaburzeń, Wydawnictwo Ergo-Sum, Bytom 2017; D. Pluta-Wojciechowska, Efektywność terapii dyslalii. Logopedyczno-lingwistyczna analiza wyników badań, Wydawnictwo Uniwersytetu Śląskiego, Katowice 2019. 
a) 34 children with comorbid disorders of the sound realization of dentalised phonemes (10 girls and 24 boys),

b) 34 children not revealing disorders of the sound realization of phonemes (12 girls and 22 boys).

Table 5. Criteria for exclusion from the research sample

\begin{tabular}{|l|l|}
\hline $\begin{array}{c}\text { Children with disorders of the sound } \\
\text { realization of dentalised phonemes }\end{array}$ & $\begin{array}{c}\text { Children without disorders } \\
\text { of the sound realization of phonemes }\end{array}$ \\
\hline $\begin{array}{l}\text { no written consent from the parents/legal guardians for the participation of their } \\
\text { child in the study }\end{array}$ \\
\hline no consent from the headmaster of the school to conduct the study in the facility \\
\hline $\begin{array}{l}\text { presence of disorders of the sound reali- } \\
\text { zation of phonemes other than dentalised } \\
\text { phonemes (in the auditory assessment) }\end{array}$ \\
\hline
\end{tabular}

Depending on the number of students participating in the study in a given institution, the completion of the questionnaire was conducted in direct contact between the researcher and the examined person or in small groups. At this age, the reading skills of children still remain at varying levels, so the person conducting the study read the consecutive statements aloud and, if necessary, clarified any doubts on an ongoing basis. Children who were able to read fluently could continue to complete the test sheet at their own pace. The biggest problem was noticed in the understanding of the reverse diagnostic questions, so the author had to reformulate them relatively often so that they would become understandable to minor respondents.

After collecting all the necessary data, the research material was organised with division into individual scales and subscales, and an analysis was carried out by comparing the results obtained in two groups using the Student's t-test for independent samples. The self-esteem scale comprised 10 statements, including four reverse diagnostic tasks: 
1. I believe that I deserve praise as much as my colleagues.

2. I do many things well enough.

3. I love myself.

4. I like my physical appearance.

5. In fact, I can handle everything as well as others.

6. I am ok.

7. It happens that I am worried about what I am.

8. It happens that I am not satisfied with myself.

9. It happens that I feel hopeless.

10. It happens that I feel a little worse than others.

The analysis of the test results was conducted in relation to the four-point graphical scale presented in the test sheet, bearing in mind that in the reverse diagnostic questions the scores should be reversed according to the rule: $4=1,3=2,2=3,1=4 .{ }^{43}$ To compare the results of children revealing disorders of the sound realization of dentalised phonemes (in other words: children with a speech impediment of the sigmatism type, children with an articulation disorder of the sigmatism type) with the results of children not revealing articulation disorders, only raw scores were used, because the normal sten scores for the group of girls and boys were calculated separately for each gender. However, the interpretation of the obtained sten ranges for each group was formulated on the basis of the key to the description of results, which is one of the appendices in the test manual, as well as in reference to the literature explaining the social and psychological symptoms of low, average or high self-esteem.

During the analysis of the results of the collected data on the self-esteem scale for the group of girls revealing disorders of the sound realization of dentalised phonemes and not revealing articulation disorders (Table 6 and Table 7), it was observed that the group of girls with a speech impediment seems to constitute a more

43 J. Góźdź, E. Wysocka, Kwestionariusz Nastawień Intrapersonalnych, Interpersonalnych i Nastawień wobec Świata (KNIIŚ). Podręcznik testu - wersji dla uczniów szkoły podstawowej klas I-III, Ministry of National Education, Warsaw 2011, p. 44. 
homogeneous group, as the differentiation of the mean raw scores is 12 pts., and the mean score is in the range of 24.52; 32.28 and corresponds to the range of sten scores of 3; 6 (low results - average results).

Table 6. Self-esteem Raw scores for groups of girls and boys

\begin{tabular}{|l|c|c|c|c|}
\hline Group name & $\begin{array}{c}\text { Girls with a speech } \\
\text { impediment of the } \\
\text { sigmatism type }\end{array}$ & $\begin{array}{c}\text { Girls with } \\
\text { no speech } \\
\text { impediments }\end{array}$ & $\begin{array}{c}\text { Boys with a speech } \\
\text { impediment of the } \\
\text { sigmatism type }\end{array}$ & $\begin{array}{c}\text { Boys with } \\
\text { no speech } \\
\text { impediments }\end{array}$ \\
\hline Number of respondents & 10 & 12 & 24 & 22 \\
\hline Mean & 28.9 & 29.5 & 30.08 & 30.91 \\
\hline Median & 29.5 & 31 & 31 & 31 \\
\hline Standard deviation & \pm 3.38 & \pm 5.45 & \pm 4.99 & \pm 4.79 \\
\hline Range of results & 12 & 18 & 29 & 16 \\
\hline Minimum & 23 & 20 & 19 & 24 \\
\hline Maximum & 35 & 38 & 39 & 40 \\
\hline Mean raw score range & $25.52 ; 32.28$ & $24.05 ; 34.95$ & $25.09 ; 35.07$ & $26.12 ; 35.7$ \\
\hline
\end{tabular}

Table 7. Self-esteem Sten scores for groups of girls and boys*

\begin{tabular}{|l|c|c|c|c|}
\hline \multicolumn{1}{|c|}{ Group name } & $\begin{array}{c}\text { Girls with a speech } \\
\text { impediment of the } \\
\text { sigmatism type }\end{array}$ & $\begin{array}{c}\text { Girls with } \\
\text { no speech } \\
\text { impediments }\end{array}$ & $\begin{array}{c}\text { Boys with a speech } \\
\text { impediment of the } \\
\text { sigmatism type }\end{array}$ & $\begin{array}{c}\text { Boys with } \\
\text { no speech } \\
\text { impediments }\end{array}$ \\
\hline Number of respondents & 10 & 12 & 24 & 22 \\
\hline Mean sten score & 4 & 5 & 5 & 5 \\
\hline Median & 5 & 6 & 6 & 6 \\
\hline Standard deviation & \pm 1.69 & \pm 2.45 & \pm 2.09 & \pm 2.12 \\
\hline Range of results & 6 & 8 & 9 & 7 \\
\hline Minimum & 2 & 1 & 1 & 3 \\
\hline Maximum & 8 & 9 & 10 & 10 \\
\hline Mean sten score range & $3 ; 6$ & $2 ; 7$ & $3 ; 7$ & $4 ; 7$ \\
\hline
\end{tabular}

* Explanations: The mean sten score ranges are presented as integers, and the mean sten scores in each group were assumed in relation to the calculated mean value of the raw scores. 
The lowest mean sten scores for the group of girls revealing articulation disorders of the sigmatism type were at the sten level 3, which means that the respondents obtained scores close to the upper limit of the low score range in terms of self-esteem. According to the key to the interpretation of the research results, the range of low scores in the area of self-esteem suggests that there may be a basis for the conclusions that children have problems with developing a positive self-image. This means that children can express negative judgements and emotions towards themselves, focus on their weaknesses, and show dissatisfaction with who and what they are. In a child with a negative self-image, upward social comparisons, or "others are better than me" dominate, and the difficulties in adapting to new situations and fear of changes may also be present. As reported in the literature, in some cases low self-esteem may result in the appearance of suicidal thoughts or under some circumstances lead to depression. ${ }^{44}$ Children with low self-esteem are susceptible to hurt and unpleasantness, and more often cause behavioural issues.

The highest mean sten scores for this group reach the level of 6 stens, which means that the respondents achieve the level of the upper limit of the range of average results. However, the average result should be considered alarming as it proves the student's ambivalent attitude towards themselves. The child thinks about themselves in two categories - a positive and negative one, without showing a tendency to compare themselves with others. However, they are uncertain whether they are "good enough", lovable or valuable.

Therefore, the obtained results should constitute a source of pedagogical reflection and raise in teachers the inner conviction about the need to strengthen the student's faith in their own abilities, minimise the feeling of dissatisfaction and focus on developing such positive qualities that will become the foundation for building a new, better self-image.

44 A. Góralewska-Słońska, Poczucie własnej wartości jako potencjał jednostki, “Problemy Profesjologii" no. 2, 2011, p. 101. 
Moving on to the scores of girls without articulation disorders, the value of the standard deviation in this group is 5.45, which suggests that the scores are less focused around the mean than in the group of girls with a speech impediment. Moreover, the range of raw scores in this group is 18 pts., and the mean raw score is in the range of $24.05 ; 34.95$, thus corresponding to the range of sten scores of 2, 7 (low scores - high scores).

The lowest mean sten scores were at the sten level 2, which means that the respondents obtained scores close to the upper limit of the low score range in terms of self-esteem. Interpretation for the level of 2 stens is similar to that for 3 stens - described above - as the key to the research tool only includes interpretation for three sten ranges, and not for each individual sten. Nevertheless, it should be emphasised that in this case the range of mean sten scores is slightly more dispersed 2; 7, which is a difference of one sten in the lower and upper limits of the range in comparison with girls with disorders of the sound realization of dentalised phonemes. A sten score of 7 , which is the lower limit of the high score range, indicates a positive attitude of the student towards themselves and the individual belief that they are "good enough", respectable and lovable person. Based on such an analysis result, it can be assumed that the student shows self-acceptance and complacency, perceives and appreciates their strengths and has positive emotions towards themselves, without feeling inferior to others. High self-esteem is conducive to shaping assertive attitude, as well as accepting criticism and drawing conclusions for the future from failures. ${ }^{45}$

A similar tendency was not noted in the groups of boys revealing articulation disorders of the sigmatism type and not revealing such disorders, because the range of raw scores shows that the group of boys without speech impediments is more homogeneous. However, in both groups the scores differ from the mean to a similar extent, as the value of the standard deviation for the boys with

${ }^{45}$ M. Ryś, Ksztattowanie się poczucia własnej wartości $i$ relacji z innymi w różnych systemach rodzinnych, "Kwartalnik naukowy" 2(6), 2011, p. 78. 
a speech impediment is 4.99 and for the boys without a speech impediment is 4.79 . In the group of boys presenting articulation disorders of the sigmatism type, the mean raw score is in the range of $25.09 ; 25.07$ and corresponds to the same range of sten scores of $3 ; 7$ (low scores - high scores).

The lowest mean sten scores for this group of respondents were at the level of 3 stens, which indicates that the study boys obtained results close to the upper limit of the low scores on the self-esteem scale. A sten score of 3 suggests that the student has a negative attitude towards themselves and feels inferior to their peers. Moreover, the study by S. Coopersmith (1967) revealed that boys with decreased self-esteem set themselves significantly lower goals and achieved worse results than boys with positive self-image. 46

Moving on to the highest mean raw scores, boys with a speech impediment of the sigmatism type achieved a sten score of 7 , which allows for a conclusion that they create a positive self-image. They do not feel inferior to their peers, thanks to which they feel positive emotions when thinking about themselves. In the study of S. Coopersmith, boys with high self-esteem set themselves higher and more realistic goals, were more inclined to undertake effort and new challenges, as well as to cooperate in a group. Moreover, they showed greater emotional expression. ${ }^{47}$

In the case of boys not revealing articulation disorders, the range of mean raw scores is 26.12; 35.7, and the mean of the raw scores is 30.91 pts., which on the scale of sten scores indicates the level of 5 stens, i.e. the lower limit of the average scores. On this basis, it can be concluded that such a student has a relatively positive attitude towards themselves, although they do not always accept themselves and are often dissatisfied with themselves. All their

${ }^{46}$ A. Malecha, Samoocena a funkcjonowanie dziecka w warunkach klasy szkolnej, [in:] Wspótczesne trendy w edukacji dziecka, ed. M. Styczyński, M. Olejniczak, Konin 2015, p. 136, [after]: S. Coopersmith, The antecedents of self-esteem, San Francisco 1967.

${ }^{47}$ A. Malecha, Samoocena a funkcjonowanie dziecka w warunkach klasy szkolnej, [after:] Wspótczesne trendy w edukacji dziecka, ed. M. Styczyński, M. Olejniczak, Konin 2015, p. 136, [after]: S. Coopersmith, The antecedents of self-esteem, San Francisco 1967. 
accompanying emotions become bilateral, or sometimes they are positive and sometimes negative. Importantly, they do not show a tendency to compare themselves with others according to the rule that: "Others are better than me." They require actions aimed at building self-confidence and strengthening the courage to overcome the encountered obstacles and difficulties. It is worth adding that the range of sten scores in this group of the study boys is the same as in the case of boys with disorders of the sound realization of dentalised phonemes, therefore the interpretation stage was intentionally omitted, as it is identical to the description provided in the two previous paragraphs.

Table 8. Self-esteem Raw results for groups of children with and without a speech impediment

\begin{tabular}{|l|c|c|}
\hline \multicolumn{1}{|c|}{ Group name } & $\begin{array}{c}\text { Girls with a speech impediment } \\
\text { of the sigmatism type }\end{array}$ & $\begin{array}{c}\text { Girls with } \\
\text { no speech } \\
\text { impediments }\end{array}$ \\
\hline Number of respondents & 34 & 34 \\
\hline Mean & 29.74 & 30.41 \\
\hline Median & 30 & 31 \\
\hline Standard deviation & \pm 4.55 & 5 \\
\hline Range of results & 20 & 20 \\
\hline Minimum & 19 & 40 \\
\hline Maximum & 39 & \\
\hline Student's t-test & \multicolumn{2}{|c|}{0.583} \\
\hline Significance level & $(25.19 ; 34.29)$ & $(25.41 ; 35.41)$ \\
\hline Mean raw score range & \multicolumn{2}{|c|}{} \\
\hline
\end{tabular}

When analysing the results of the study relevant to the undertaken research issues (Table 8), or the comparison of the results obtained in the group of children with a speech impediment of the sigmatism type and the group of children without articulation disorders, attention should be paid to the result of the Student's t-test 
for independent samples $t=0.58(p=0.564)$. The obtained result indicates that the revealed differences in the level of self-esteem in the study groups are not statistically significant. The lower limit of the raw results range, both in the group of girls and boys, corresponds to approx. $63 \%$ of the maximum result, and the upper limit to approx. $85 \%$ of the highest score possible to be obtained in the study. In both groups, the results deviate from the mean by similar values, and the difference between the scores of students with high and low self-esteem is $\mathrm{R}=20$ pts., allowing for a large dispersion of the results obtained by the tested students. The distribution of raw results presented in the histograms (Figure 2) allows for the observation of the tendency that the majority of results, both in the group

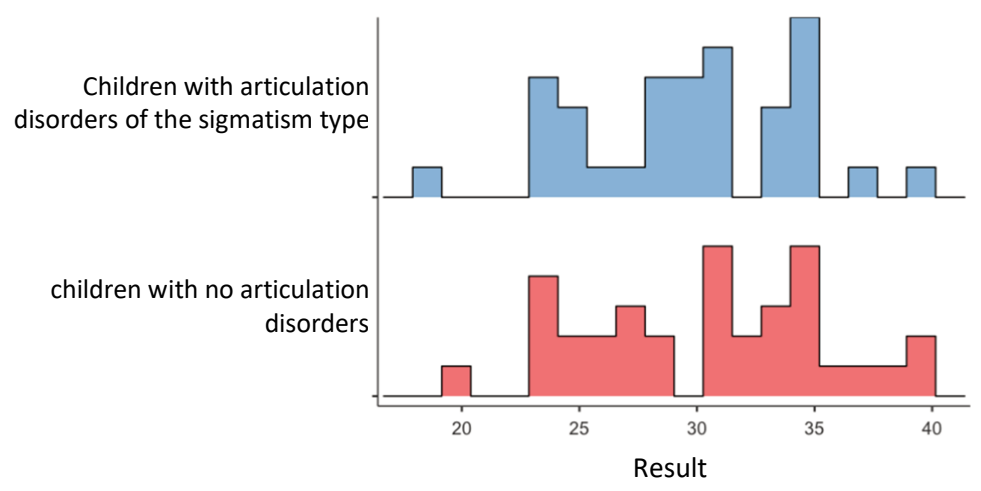

Figure 2. Histograms with distribution of raw scores in groups of children with a speech impediment of the sigmatism type and children with no speech impediment

of children with a speech impediment of the sigmatism type, and in the group of children without articulation disorders, are located in the range of 23;35 points. The highest result in the group of children with articulation disorders was 39 pts. and the lowest - 19 pts. A similar, but slightly higher result at the level of 40 pts. was observed in the group of students without articulation disorders. In turn, the lowest score in this group of the study children was 20 pts. The higher value 
of the standard deviation in the two groups $(\mathrm{SD}=4.55$ in the group of children with a speech impediment and $\mathrm{SD}=5$ in the group of children without articulation disorders) indicates a greater dispersion of the results. ${ }^{4} 8$

In the specific nature of the purposive selection of the sample it is assumed that the formed research samples do not represent the population, and thus can be used only in individualising research. Therefore, there are no grounds for generalising the obtained research results and drawing general conclusions for the population ${ }^{49}$. The conclusion that the articulation disorder of the sigmatism type is irrelevant to the level of self-esteem of a child completing the stage of early school education is true only for the collected observations. Regardless of the presence or absence of disorders of the sound realization of dentalised phonemes, the results of both study groups on the self-esteem scale fluctuate around the average level.

Table 9. Data for the interpretation of violin boxes

\begin{tabular}{|l|c|c|}
\hline \multicolumn{1}{|c|}{ Group name } & $\begin{array}{c}\text { Children with a speech } \\
\text { impediment } \\
\text { of the sigmatism type }\end{array}$ & $\begin{array}{c}\text { Children with no speech } \\
\text { impediments }\end{array}$ \\
\hline Percentile 25 (Q1) & 26.3 & 26.3 \\
\hline Percentile 50 (median) & 30 & 31 \\
\hline Percentile 75 (Q3) & 33 & 34 \\
\hline Interquartile range (IQR) & 6.7 & 7.7 \\
\hline
\end{tabular}

The violin box is the modern successor to the box plot invented by J. Tukey in $1970 . .^{50}$ It constitutes a combination of a box plot and a density plot. Although it is not so popular, it allows for a clear

48 B.M. King, E.W. Minium, Statystyka dla psychologów i pedagogów, tłum. Marzenna Zakrzewska, Wydawnictwo Naukowe PWN, Warszawa 2020, s. 125.

${ }^{49} \mathrm{~K}$. Konarzewski, Jak uprawiać badania oświatowe. Metodologia praktyczna, WSiP, Warszawa 2000, s. 108.

${ }^{50}$ H. Wickham, L. Stryjewski, 40 years of boxplots, 2011, p. 2. 
presentation of data. In the above plots it can be observed that their shape and observation dispersion in individual samples are similar. The wider sections of the violin plot represent a higher probability of an observation of a particular value, and the narrower sections correspond to a lower probability. $25 \%$ of people in each of the study samples obtained results equal to or lower than the value of the first quartile, or 26.3 pts. In the group of children with articulation disorders, $25 \%$ of the respondents obtained a score of $\geq 33$ pts., while $25 \%$ of the respondents in the group of children not revealing articulation disorders obtained a result of $\geq 34$ pts.

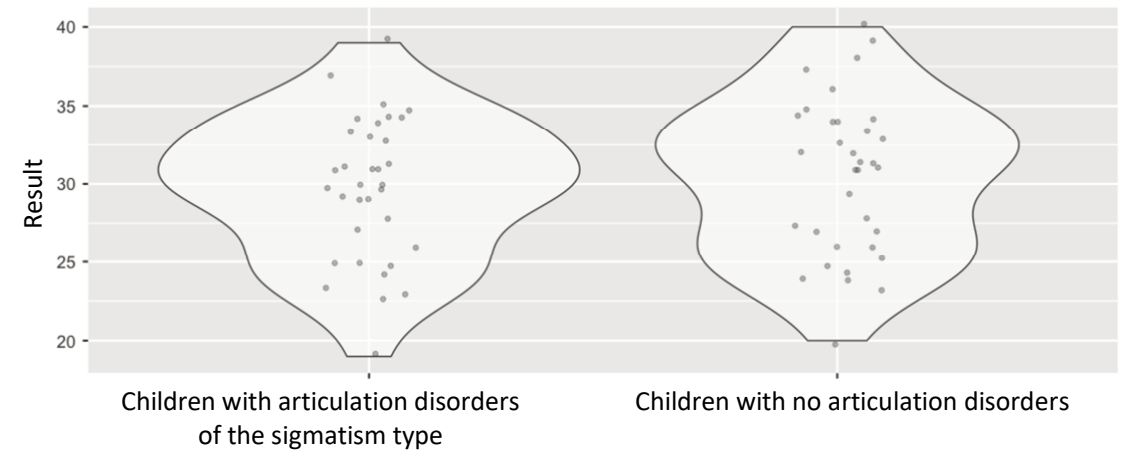

Figure 3. Distribution of raw results in the groups of children with articulation disorders of the sigmatism type and children without articulation disorders presented in violin boxes

$50 \%$ of the study observations are present in the interquartile range (IQR), defined as the difference between the value of the first and third quartiles. The greater the width of the IQR, the greater the measure of differentiation of the study trait in the sample. And so, the interquartile range in the group of children without articulation disorders is greater than in the group of children with a speech impediment of the sigmatism type, which proves a slightly greater variation in the level of self-esteem in children who do not reveal articulation disorders. 
To sum up, the discussed analysis of the results is not optimistic, as over $30 \%$ of the observations in the two studied research samples achieved a result at an average level. Another 23/68 respondents (slightly over $35 \%$ of all respondents) obtained low results, which suggests that they reveal a negative attitude towards themselves and a tendency to compare themselves with others who are "better" than themselves. Although 24 out of 68 study students (approx. $35 \%$ ) show a high level of self-esteem, the obtained results are closer to the lower limit of the high score (7-8 stens). Only 4 people, which is less than $6 \%$ of the respondents, reached the level of 9 and 10 stens.

\section{Conclusion}

The analysis of the collected research material concerning the level of self-esteem of students revealing and not revealing disorders of the sound realization of dentalised phonemes and at the same time completing the stage of early school education demonstrated that the tested students, regardless of the presence of absence of a speech impediment of the sigmatism type, present on average a mean level of self-esteem $- \pm 75 \%$ of the maximum score. Bearing in mind that the study was conducted in a group of students finishing the third grade of primary school, this result can be interpreted in two ways. On the one hand, it can be considered alarming in the context of the further psychosocial development and school functioning of students, which creates a wide field of influence for parents, teachers and other specialists who should undertake activities aimed at supporting the development of high, adequate self-esteem of the child. On the other hand, the explanation for such a result can be found in the regularities of the development of self-esteem, which in the younger school age, although becoming more and more focused, still undergoes modifications and fluctuations on the continuum from the lowered to high one 
due to dynamic changes occurring in other areas of child development and the acquired experience. ${ }^{51}$

The obtained research results seem to contradict the previous findings of researchers concerning the importance of speech impediment for the psychosocial development of a child. According to the source literature in the field of general pedagogy, special education, speech therapy, developmental psychology or social psychology, disorders in the correct formulation of understandable messages have an impact on social competence of a child. Incorrect articulation causes difficulties in decoding messages, which in turn may become a cause of the gradual isolation of a child from their social environment. Articulation barriers in communication may contribute to lowering self-esteem and a number of limitations in the development of personality and satisfaction of the basic needs of a child. ${ }^{52}$ Therefore, a low level and quality of linguistic competence imply a low level of communicative competence and, in extreme cases, may lead to an increase in fear of speaking.

E. Skorek emphasises that a child presenting communication disorders may not be an attractive interaction partner for their peers because of disorders in the communication and regulatory function of speech. A negative emotional attitude towards a child revealing speech disorders affects a sense of belonging to a group and a sense of security 53

In the present research procedure, the significance of a speech impediment of the sigmatism type for the level of self-esteem of selected students completing the stage of early school education has not been established, but the importance of the problem of articulation disorders occurring in the speech of early school-age children

${ }^{51}$ H.R. Schaffer, Rozwój społeczny. Dzieciństwo i młodość, Wydawnictwo Uniwersytetu Jagiellońskiego, Cracow 2006, pp. 175-184.

52 A. Jopkiewicz, Konsekwencje społeczne, psychologiczne i pedagogiczne nieprawidtowego rozwoju mowy u dzieci, [in:] Acta Scientifica Academiae Ostroviensis no. 8, 2001, pp. 116-117.

53 E.M. Skorek, Dzieci z zaburzeniami mowy wśród rówieśników w klasie szkolnej, Cracow 2000, p. 10. 
should be emphasised, as they may not only be significant for other dimensions of emotional and social development of students, but also constitute one of the first predictors of difficulties in learning to read and write. ${ }^{54}$

Another perspective of explanation is presented by M. Zając, who writes in the summary of the results of her study that the speech sound disorder is often treated as a simple, popular speech disorder, therefore "the self-esteem of a child, although lowered, is not much different in relation to their peers". .55

The obtained research results cannot be compared in zero-one terms with the previous analyses of the researchers because of the differences in the characteristics of the research samples, namely the age and number of respondents, as well as the type and specificity of speech disorders. It should be considered that the obtained results could change and show other tendencies if the study were conducted using other research samples, including additional variables that would allow for a more complete picture of a child with an articulation disorder, e.g. socio-economic status of the family, place of residence, level of education or self-esteem of parents, which at the stage of middle childhood is not insignificant for the level of self-esteem of their child. The identification of the abovementioned aspects would enable the analysis of the research material with the use of a correlation model, and thus the adoption of a broader perspective of interpretation.

There is also no doubt that the need to conduct multi-range, specialised and systematic research on the consequences of speech

54 Zob. B. Wołosiuk, Zaburzenia mowy a trudności w nauce czytania $i$ pisania, “Rozprawy społeczne” vol. 12, no. 4, 2018, pp. 56-64; E. Zając, Wpływ zaburzeń mowy $u$ dzieci sześcio- $i$ siedmioletnich na naukę czytania i pisania, [in:] Teoria i praktyka logopedyczna, ed. E. Gacka, M. Kaźmierczak, Łódź 2018, pp. 213-221; E. Jeżewska-Krasnodębska, Zaburzenia mowy u dzieci rozpoczynających naukę szkolną $i$ ich wptyw na trudności w zakresie czytania i pisania, [in]: Zaburzenia komunikacji jezzykowej w czytaniu i pisaniu, ed. Alina Maciejewska, Siedlce 2007, pp. 45-55.

${ }_{55}$ M. Zając, Zaburzenia rozwoju mowy a samoocena dziecka, [in:] Terapia logopedyczna, ed. D. Baczała, J. Błeszyński, Wydawnictwo Naukowe Uniwersytetu Mikołaja Kopernika, Torun 2014, p. 250. 
disorders, including speech sound disorders, in numerous areas of the functioning of a child, for example in relation to peer relationships or school achievements, is becoming more visible. Regular compilation of statistics monitoring the severity of articulation disorders among children of different ages in all voivodeships would enable a real assessment of the importance of the problem and a more effective organisation of prevention, diagnosis and speech therapy at earlier stages of education.

\section{References}

Appelt K., Wiek szkolny. Jak rozpoznać potencjał dziecka?, [in:] Psychologiczne portrety człowieka. Praktyczna psychologia rozwojowa, ed. A.I. Brzezińska, Gdańskie Wydawnictwo Psychologiczne, Gdańsk 2019, pp. 274-295.

Biernat R., Troska o poczucie własnej wartości dzieci w rzeczywistości szkolnej - wymiar teoretyczny i praktyczne implikacje, "Społeczeństwo. Edukacja. Język" no. 4, 2016, p. 162.

Borowiecki P., Samoocena osób z niepetnosprawnościa w świetle wybranej literatury $i$ badań własnych, "Niepełnosprawność - zagadnienia, problemy, rozwiązania" no. II/2015(15).

Branden N., 6 filarów poczucia własnej wartości (translated by H. Dąbrowska), Wydawnictwo Ravi, Łódź 1998, pp. 220-221.

Erikson E., Dzieciństwo i społeczeństwo, translated by Przemysław Hejmej, Dom Wydawniczy Rebis, Poznań 1997, pp. 269-272.

Gacka E., Kaźmierczak M., Przesiewowe badania mowy jako przykład dziatań z zakresu profilaktyki logopedycznej, [in:] Logopaedica Lodziensa, (no. 1), ed. I. Jaros, Łódź 2017, p. 38.

Góralewska-Słońska A., Poczucie własnej wartości jako potencjat jednostki, “Problemy Profesjologii" no. 2, 2011, p. 101.

Góźdź J., Wysocka E., Kwestionariusz Nastawień Intrapersonalnych, Interpersonalnych i Nastawień wobec Świata (KNIIŚ). Podręcznik testu - wersja dla uczniów szkoły podstawowej klas I - III, Ministry of National Education, Warsaw 2011, pp. 39-41.

Jędrzejewska A., Samoocena dziecka - źódta i komunikaty weryfikujace, "Zbliżenia Cywilizacyjne" no. 1(1) 2016, pp. 144-161.

Jopkiewicz A., Konsekwencje społeczne, psychologiczne i pedagogiczne nieprawidłowego rozwoju mowy u dzieci, [in:] Acta Scientifica Academiae Ostroviensis no. 8, 2001, p. 119.

Kamza A., Rozwój dziecka. Wczesny wiek szkolny, [in:] Niezbędnik dobrego nauczyciela. Rozwój w okresie dzieciństwa i dorastania T3, (ed.) A. Brzezińska, Warsaw 2014, p. 28. 
Kirby J.R., Williams N.H., Learning Problems. A Cognitive Approach. Toronto 1991.

Knopik M., Zaburzona komunikacja a relacje społeczne. Zagrożenia i strategie wsparcia, [in:] Uczeń ze specjalnymi potrzebami edukacyjnymi, ed. E. Domagała-Zyśk, Lublin 2012, pp. 30-36.

Knychalska-Zbierańska M., Sposób postrzegania osób $z$ wada wymowy przez społeczeństwo. Badania wtasne, [in:] Logopedia Silesiana 4, Katowice 2015, p. 385.

Konarzewski K., Jak uprawiać badania oświatowe. Metodologia praktyczna, WSiP, Warsaw 2000, pp. 12-47.

Kulas H., Samoocena młodzieży, Wydawnictwa Szkolne i Pedagogiczne, Warsaw 1986, p. 9.

Lerner R.M., Hultsch D.V., Human Development. A life-span perspective, McGraw-Hill 1983, pp. 5-6.

Lewandowska-Kidoń T., Wosik-Kowala D., Rozwijanie poczucia własnej wartości u dzieci w młodszym wieku szkolnym, Cracow 2009, pp. 20-24.

Malecha A., Samoocena a funkcjonowanie dziecka w warunkach klasy szkolnej, [in:] Wspótczesne trendy w edukacji dziecka, ed. M. Styczyński, M. Olejniczak, Konin 2015, p. 136, [after]: S. Coopersmith, The antecedents of self-esteem, San Francisco 1967.

Minczakiewicz E.M., Dyslalia na tle innych wad i zaburzeń mowy u dzieci w wieku przedszkolnym i szkolnym, [in:] Konteksty Pedagogiczne 1(8)/2017 Warsaw, p. 160.

Niebrzydowski L., O poznawaniu i ocenie samego siebie, Wydawnictwo Nasza Księgarnia, Warsaw 1976, p. 52.

Pluta-Wojciechowska D., Dyslalia obwodowa. Diagnoza $i$ terapia logopedyczna wybranych form zaburzeń, Wydawnictwo Ergo-Sum, Bytom 2017, p. 273.

Pluta-Wojciechowska D., Zaburzenia czynności prymarnych i artykulacji, Wydawnictwo Ergo-Sum, Bytom 2015, p. 168.

Rosenberg M., Society and adolescent self-image, Princeton University Press, New York 1965, pp. 30-31.

Ryś M., Ksztattowanie się poczucia własnej wartości i relacji z innymi w różnych systemach rodzinnych, "Kwartalnik naukowy" 2(6), 2011, p. 77.

Sameroff A., A Unified Theory of Development: A Dialectic Integration of Nature and Nurture, "Child Development", vol. 81(1), 2010, p. 16.

Schaffer R.H., Psychologia dziecka, Wydawnictwo PWN, Warsaw 2007, p. 336.

Schaffer H.R., Rozwój społeczny. Dzieciństwo i młodość, Wydawnictwo Uniwersytetu Jagiellońskiego, Cracow 2006, pp. 169-184.

Stecko E., Zaburzenia mowy u dzieci. Wczesne rozpoznawanie $i$ postępowanie logopedyczne, Wydawnictwo Uniwersytetu Warszawskiego, Warsaw 2002, p. 54.

Supińska M., Dzieci izolowane i odrzucone, “Życie Szkoły” no. 2, 2003, p. 89, [after:] R. Biernat, Troska o poczucie własnej wartości dzieci w rzeczywistości szkolnej - wymiar teoretyczny i praktyczne implikacje, "Społeczeństwo. Edukacja. Język" no. 4, 2016, p. 163. 
Szpitlak M., Polczyk R., Samoocena. Geneza, struktura, funkcje i metody pomiaru, Wydawnictwo Uniwersytetu Jagiellońskiego, Cracow 2015, p. 10.

Tomik J., Solowska B., Wczesne wykrywanie wad rozwojowych u dzieci w wieku szkolnym w zakresie zaburzeń stuchu i wad wymowy, Cracow 2018, p. 10.

Wickham H., Stryjewski L., 40 years of boxplots, 2011, p. 2.

Zając M., Zaburzenia rozwoju mowy a samoocena dziecka, [in:] Terapia logopedyczna, ed. D. Baczała, J. Błeszyński, Wydawnictwo Naukowe Uniwersytetu Mikołaja Kopernika, Torun 2014, p. 250. 